\title{
Intake of Animal Protein and Dietary Sources in the Colombian Population: Results of the National Nutrition Survey (ENSIN-2015)
}

\author{
Oscar F. Herrán ${ }_{(D)}^{1}$ and María del Pila Zea $\left.{ }^{2}\right)^{2}$ \\ ${ }^{1}$ Escuela de Nutrición y Dietética, Universidad Industrial de Santander, Carrera 32 No. 29-31, Bucaramanga, \\ Santander, Colombia \\ ${ }^{2}$ Universidad Javeriana de Cali, Facultad de Ciencias de la Salud, Calle 17 \# 121B-80, Cali, Valle del Cauca, Colombia \\ Correspondence should be addressed to Oscar F. Herrán; herran@uis.edu.co
}

Received 8 October 2021; Accepted 23 December 2021; Published 13 January 2022

Academic Editor: Roxana Valdés-Ramos

Copyright ( 92022 Oscar F. Herrán and María del Pila Zea. This is an open access article distributed under the Creative Commons Attribution License, which permits unrestricted use, distribution, and reproduction in any medium, provided the original work is properly cited.

\begin{abstract}
Background. There is a lack of knowledge in Colombia about dietary intake and sources of animal protein. Design. Crosssectional, nationally representative surveys. Setting. Colombia. Participants. $n=32,457$ participants aged from 1 to 64 years. The sample analyzed included 21,036 boys and nonpregnant girls, 10,099 adults, and 1,322 pregnant women, 118 of whom were below 18 years of age. Results. Protein intake was 32.9 g/d (95\% CI: 32.4, 33.4) per 1,000 kilocalories. The relative contribution (\%) of total protein to the total energy intake/day (acceptable macronutrient distribution) was 13.2\% (95\% CI: 13.0, 13.3). The acceptable macronutrient distribution (AMDR) for animal protein for those aged 1 to 64 years was 7.8\% (95\% CI: 7.6, 8.0), with a minimum of $7.1 \%$ (95\% CI: 6.7, 7.5), which was for children aged from 13 to 17 years, and a maximum of 8.3\% (95\% CI: 8.1, $8.5)$, for children aged from 1 to 4 years $(P=0.018)$. For all groups, animal protein made up the majority of total proteins, with 62.6\% (95\% CI: 61.7, 63.6) for preschoolers, 55.8\% (95\% CI: 53.2, 58.4) for school-aged children, 54.6\% (95\% CI: 53.0, 56.1) for adolescents, 58.1\% (95\% CI: 57.5, 58.7) for adults, and 57.5\% (95\% CI: 55.2, 59.7) for pregnant women $(P=0.027)$. The three main dietary sources of animal protein were red meat (17.8\%), chicken $(16.3 \%)$, and eggs $(10.5 \%)$. The sources of vegetal protein were bread-arepa-pasta (20.0\%), cereals (19.8\%), and legumes (8.2\%). Conclusions. Protein intake is excessive according to the Recommended Dietary Allowance (RDA), while it is not excessive from the perspective of the AMDR.
\end{abstract}

\section{Introduction}

The importance of protein for the human diet is indisputable [1-4]. The quantity consumed (g), its animal or vegetable origin, and the dietary sources are synonymous with its quality [2]. The U.S. Institute of Medicine's recommended daily allowance for protein is 1.05 gram per kilogram per day $(\mathrm{g} / \mathrm{kg} /$ day) for children aged from 1 to 3 years, $0.95 \mathrm{~g} / \mathrm{kg} / \mathrm{d}$ for children aged from 4 to 13 years $(19 \mathrm{~g} /$ $\mathrm{d}$ for girls and $34 \mathrm{~g} / \mathrm{d}$ for boys), $0.85 \mathrm{~g} / \mathrm{kg} / \mathrm{d}$ for adolescents aged from 14 to 18 years $(52 \mathrm{~g} / \mathrm{d}$ for males and $46 \mathrm{~g} / \mathrm{d}$ for females), and $0.8 \mathrm{~g} / \mathrm{kg} / \mathrm{d}$ for adults. For pregnant women, the RDA is $1.1 \mathrm{~g} / \mathrm{kg} / \mathrm{d}$ or $25 \mathrm{~g} / \mathrm{d}$ in addition to the amount recommended for women of the same age [1]. Nevertheless, if instead of the RDA the acceptable macronutrient distribution range (AMDR) is used, in which protein accounts for 10 to $35 \%$ of the total energy/day, then the RDA would range from 1.05 to $3.67 \mathrm{~g} / \mathrm{kg} / \mathrm{d}$ [5].

The effect of excessive protein intake on the risk of death from all causes is controversial [6-8]. Protein intake from vegetable sources slightly reduces the overall risk of death and death from cardiovascular diseases (CVD) but not from cancer. In addition, the intake of total protein and protein from animal sources has not been found to be associated with death from all causes or from cardiovascular diseases or cancer [8]. The association of animal protein intake with mortality from CVD can be positive when protein intake is high relative to total energy and subjects present at least one 
risk factor related to lifestyle [7]. Animal protein intake (red meat and processed meat) can increase the risk of mortality from any cause and from CVD, while the consumption of red meat is positively associated with mortality from CVD $[9,10]$. Higher consumption of vegetable protein and lower consumption of animal protein have been associated with a lower risk of metabolic syndrome. [11]. In the United States, according to the 2007-2010 National Health and Nutrition Examination Survey (NHANES), 62\% of total protein was from animal sources (16\% from milk and milk by-products and $46 \%$ from meat, chicken, eggs, and fish) and 30\% from vegetable sources. In adults aged 19 years or older, mean animal protein intake ranged from 0.33 to 0.97 (g/ kg/d) [3]. Based on the analysis of nine NHANES cycles (1999-2016), in the population above 20 years of age, protein intake and the relative contribution of protein to total energy increased from $15.5 \%$ to $16.4 \%$, and said increase was due to both the consumption of protein of animal origin (0.44\%) and vegetable $(0.33 \%)$ sources $(P<0.001$ for trends $)$ [2]. Knowledge about whether protein intake from animal sources is predominant is lacking in Colombia, as it is in developed and middle-income countries. The dietary sources are also not known.

This study was based on data gathered from the 2015 National Nutrition Survey (ENSIN in Spanish). Its objectives included the following: (a) estimating total protein intake and animal and vegetable protein intake in the Colombian population aged from 1 to 64 years and for pregnant women, (b) relating this consumption to biological and sociodemographic variables, $(c)$ describing the intake of total protein and animal and vegetable protein as AMDR, and, lastly, $(d)$ determining the nutritional sources and their relative contribution (\%) to total protein intake and to animal and vegetable intake.

\section{Methods}

In Colombia, South America, the Colombian Institute for Family Wellbeing (ICBF in Spanish) along with the Ministry of Health (MinSalud) conducted the ENSIN-2015, which is representative of $99 \%$ of the Colombian population [12]. The ENSIN-2015 estimated dietary intake using the 24-hour recall method (24 HR) $[13,14]$. A total of 44,202 households were surveyed, representing 4,739 groups of 295 strata. The methods, study populations, scope, and limitations of the ENSIN-2015 have been previously published [12]. The target population for this analysis was children aged from 1 to 17 years, adults aged between 18 and 64 years, and pregnant girls and women. The ENSIN-2015 included 151,343 people. Protein intake was estimated in a weighted random subsample $(n=32,457)$. The sample analyzed included 21,036 boys and nonpregnant girls, 10,099 adults, and 1,322 pregnant women, 118 of whom were below 18 years of age. Of the total, 749 answered the second $24 \mathrm{HR}$.

2.1. Data Sources. The main output variables were the following: (a) total, animal, and vegetable protein intake, in grams/day $(\mathrm{g} / \mathrm{d})$ and also expressed as grams per 1,000 kilocalories consumed $[15,16]$ (proteins $(\mathrm{g} / \mathrm{d}) * 1000 /$ total kilocalories/day) (g/1000/d) and (b) the relative contribution or AMDR (\%) of food items to total intake and animal and protein intake [5]. The $24 \mathrm{HR}$ was based on the methodology developed in 1999 by the U.S. Department of Agriculture (USDA) [14, 17, 18]. In brief, this consisted of asking about dietary consumption over the last 24 hours, ensuring the completion of what is known as the Automated MultiplePass Method $[14,17,18]$. The $24 \mathrm{HR}$ had a response rate of $92 \%$. After rigorous data cleaning of the database, which was obtained from an electronic application designed to capture $24 \mathrm{HR}$ data gathered from the interview, the correct coding of the foods and preparations was ensured based on a food composition table (FCT). The FCT used in the ENSIN-2015 shows the composition of 2,703 items in $100 \mathrm{~g}$ of the edible portion. The authors supplemented the FCT with the percentage of animal protein in each item based on their experience and standard recipes, when necessary. After calculating the amount (g) of animal protein in the FCT [total protein $(\mathrm{g}) * \%$ estimated animal protein/100], the amount (g) of animal protein in $100 \mathrm{~g}$ of the item in the FCT was obtained. The amount of vegetable protein was calculated as (total protein $(\mathrm{g})$ - animal protein $(\mathrm{g})$ ). FoodCalc ${ }^{\circledR}$ v1.3 [19] was used to translate the intake recorded in the $24 \mathrm{HR}$ into energy/day (kilocalories/day) and grams of total protein, animal protein, and vegetable protein. In addition, the relative contribution (\%) of animal and vegetable protein to total protein and the relative contribution (\%) of protein intake to total energy were calculated. That was based on [(total protein $(\mathrm{g} / \mathrm{d}) * 4 /$ total kilocalories ingested/day) $* 100]$. Lastly, the amount of total protein and protein from animal and vegetable sources per kilogram of actual weight and "adequate weight" (g/kg/d) was calculated. The ENSIN-2015 calculated "adequate weight" for each individual who was underweight or overweight based on two predictive equations, one for subjects aged from 1 to 17 years and another for subjects aged from 18 to 64 years. The equations incorporated data on sex, weight, size, and age of individuals with normal nutritional status according to age group. The relative contribution (\%) of the food items to total protein and protein from animal and vegetable sources was calculated as ((total protein per item/total protein $) * 100)$, ((animal protein per item/total animal protein) $* 100)$, and ((vegetable protein per item/total vegetable protein $) * 100)$, respectively.

Nutritionists and trained staff administered the surveys to obtain sociodemographic data on the households and biological data from individuals. Household food insecurity was determined using the Latin America and Caribbean Scale (ELCSA in Spanish) adopted by the United Nations Food and Agriculture Organization (FAO) [20]. This 15question scale is based on the perception of uncertainty and concern about access to food and the experience of a reduced amount of food. The ELCSA classifies households as secure and insecure and the level of food insecurity as low, moderate, and severe [20]. The wealth index is a continuous indicator of the socioeconomic level of the household and was categorized by quartiles. It was determined in the total of sample of the survey (ENSIN-2015) based on a principal 
components analysis of the sets of physical household characteristics and goods and services available, all predetermined by international demographic and health surveys [21]. Educational level of the head of household was determined based on years of study with a passing grade. The geographic region is a variable that represents the country and its degree of structural development, economic conditions, and the culture of the subjects. Colombia has 5 geographic regions $[12,22]$, where Bogotá is the capital of the country and has the highest human development index, with the central region. The Pacific and the AmazoniaOrinoquia regions are the poorest. In terms of race, the population of the Pacific region is predominantly Black, and that of the Amazonia-Orinoquia region is predominantly indigenous and mestizo [23]. The degree of urbanism was categorized according to three categories based on population density: urban centers and large cities with over 1 million residents, small towns with $100,000 \geq 1$ million residents, and dispersed populations with less than 100,000 residents [12].

Anthropometric measurements were obtained from all household members using well-known standard techniques and calibrated instruments [24]. The ENSIN-2015 used stadiometers to measure height (ShorrBoard) with a sensitivity of $1 \mathrm{~mm}$ and digital scales (SECA 874) to measure weight with a precision of $100 \mathrm{~g}$. For children, $Z$-scores were determined for height-for-age and body mass index (BMI), in accordance with growth standards by the World Health Organization (WHO) [25].

2.2. Data Analysis. The distributions of kilocalorie and protein intake were normalized and corrected to incorporate intraperson variability using methods proposed by the University of Iowa, with PC-Side v1.0 software [26]. All the analyses incorporated the effect of the complex sampling design with Stata v14.1 [27]. The analysis was aimed at (a) describing the intake of total protein and animal and vegetable protein adjusted by energy density $(\mathrm{g} / 1000 / \mathrm{d})$ for the categories of the socioeconomic variables, (b) establishing crude and adjusted differences in animal and vegetable protein intake $(\mathrm{g} / 1000 / \mathrm{d})$ for the categories of the variables studied, using simple and multiple linear regression models with protein intake $(\mathrm{g} / 1000 / \mathrm{d})$ as the dependent variable and the covariables as explanatory variables, (c) determining the relative contribution (\%) of total protein intake to total energy/day (kilocalories/day), (d) establishing the relative contribution (\%) of animal and vegetable protein to total protein/day, (e) establishing the relative contribution (\%) of food items to total protein and animal and vegetable protein intake by age group and for pregnant women, and (f) determining the amount of total protein $(\mathrm{g} / \mathrm{d})$ and animal and vegetable protein $(\mathrm{g} / 1000 / \mathrm{d})$ per kilo of actual weight and "adequate" weight. The description was performed with averages or proportions \pm the standard error (SE) and 95\% confidence intervals (95\% CI).

This study was conducted in accordance with the guidelines set forth by the Declaration of Helsinki [28]. Consent for participation in the study was obtained by the
Colombian Institute for Family Wellbeing prior to inclusion $[12,29]$. The health research ethics committee of Universidad Industrial de Santander determined that the analyses of these anonymized data were exempt from review.

\section{Results}

Mean protein intake by the Colombian population aged from 1 to 64 years is $32.9 \mathrm{~g} / 1000 / \mathrm{d}$ ( $95 \%$ CI: $32.4,33.4$ ), animal protein intake is $19.4 \mathrm{~g} / 1000 / \mathrm{d}$ ( $95 \% \mathrm{CI}: 18.9,19.8)$, and vegetable protein is $13.9 \mathrm{~g} / 1000 / \mathrm{d}$ (95\% CI: 13.5, 14.2) (Table 1). The relative contribution of animal protein to total energy in the study population (age from 1 to 64 years) is 7.8\% (95\% CI: 7.6, 8.0), with a minimum of $7.1 \%$ (95\% CI: 6.7, 7.5) for those aged from 13 to 17 years and a maximum of $8.3 \%$ (95\% CI: 8.1, 8.5) for children aged from 1 to 4 years, $P=0.018$ (Tables 1S-5S). Table 1 presents the consumption details for each sociodemographic variable. Animal protein intake is positively associated with wealth level and region. Intake is $2.5 \mathrm{~g} / 1000 / \mathrm{d}$ greater in Bogotá, the capital of the country, than in the central region, and it is lowest in the Pacific, which is the poorest region, $P=0.002$ (Table 2). More vegetable protein is consumed in the five main cities than in the rest of the cities, $P=0.026$ (Table 3). No differences were found in animal or vegetable protein intake $(P \geq 0.05)$ among any of the categories related to age group, nutritional status, food security, or education of head of household. For children aged from 5 to 12 years, females consume more animal protein than males, $P=0.031$ (Table 2).

In the overall population aged from 1 to 64 years, the three main sources of total animal protein intake are, in order, meat $(17.8 \%)$, chicken (16.3\%), and eggs (10.5\%). The three main sources of total vegetable protein intake are bread-arepa-pasta (20\%, primarily wheat and corn), cereals (19.8\%, mainly rice), and legumes (8.2\%) (Table 4). Table 6S shows the contribution (\%) of dietary sources to protein intake by age group. The relative contribution of animal protein to total protein is $56.6 \%$ (95\% CI: 55.1, 58.0). Animal protein makes up the majority of the protein intake for all age groups: $62.6 \%$ (95\% CI: 61.7, 63.6) for preschoolers, $55.8 \%$ (95\% CI: 53.2, 58.4) for school-aged children, 54.6\% (95\% CI: 53.0, 56.1) for adolescents, $58.1 \%$ (95\% CI: $57.5,58.7)$ for adults, and $57.5 \%$ (95\% CI: 55.2 , 59.7) for pregnant women, $P=0.027$ (Tables $1 \mathrm{~S}-5 \mathrm{~S}$ and Figure 1).

For the overall population, the relative contribution (\%) of total proteins to the total energy/day is $13.2 \%$ (95\% CI: 13.0, $13.3)$, with a minimum of $12.7 \%$ (95\% CI: $12.2,13.2)$ for adolescents and a maximum of $13.3 \%$ (95\% CI: 13.1, 13.6) for adults (Tables 1S-5S). These tables also show the mean total protein intake and mean animal and vegetable intake per age group and sex for the actual weight and the theoretically ideal weight. Milk is the main source of protein for children aged from 1 to 4 years (10.1\%), and chicken (11.3\%) and meat $(11.2 \%)$ are the main sources for adolescents. For pregnant women, mean animal protein intake (average \pm SD) is $20.9 \pm 1.5 \mathrm{~g} / 1000 / \mathrm{d}$ and mean vegetable protein intake is $14.3 \pm 0.8 \mathrm{~g} / 1000 / \mathrm{d}$. Tables $7 \mathrm{~S}-18 \mathrm{~S}$ present the protein intake's details per age group and the relationships with some of the socioeconomic variables. 
TABLE 1: Sociodemographic characteristics of the Colombian population (aged from 1 to 64 years, nonpregnant women) with estimates of the consumption of animal and vegetable protein, $\mathrm{g} / \mathrm{d}$ for every $1000 \mathrm{kcal}$ consumed (National Survey of Nutritional Situation in Colombia (ENSIN-2015)).

\begin{tabular}{|c|c|c|c|c|c|}
\hline \multirow{2}{*}{ Variable } & \multirow{2}{*}{$n$} & \multicolumn{2}{|c|}{ Animal protein* } & \multicolumn{2}{|c|}{ Vegetal protein* (plants) } \\
\hline & & Mean $(\mathrm{g} / \mathrm{d})^{\dagger}$ & SE & Mean $(\mathrm{g} / \mathrm{d})^{\dagger}$ & SE \\
\hline Overall & 31135 & 19.4 & 0.2 & 13.9 & 0.2 \\
\hline \multicolumn{6}{|l|}{ Sex } \\
\hline Males & 15265 & 18.8 & 0.4 & 14.0 & 0.3 \\
\hline Females & 15870 & 19.9 & 0.2 & 13.7 & 0.1 \\
\hline \multicolumn{6}{|l|}{ Age group (y) } \\
\hline Preschool children (1-4) & 6803 & 20.8 & 0.2 & 12.9 & 0.4 \\
\hline Schoolchildren (5-12) & 6692 & 18.2 & 0.5 & 14.7 & 0.7 \\
\hline Adolescents (13-17) & 7541 & 17.8 & 0.5 & 14.0 & 0.2 \\
\hline Young adults (18-26) & 2147 & 18.6 & 0.3 & 13.6 & 0.2 \\
\hline Adults $(27-49)$ & 5332 & 20.2 & 0.4 & 13.7 & 0.2 \\
\hline Older adults (50-64) & 2620 & 20.3 & 0.4 & 13.8 & 0.2 \\
\hline \multicolumn{6}{|l|}{ Height-for-age Z-score ${ }^{\ddagger}$} \\
\hline$<-2$ & 1995 & 19.6 & 0.6 & 13.8 & 0.2 \\
\hline-2 to $<-1$ & 5451 & 19.3 & 0.3 & 13.9 & 0.2 \\
\hline-1 to 1 & 11040 & 19.3 & 0.3 & 13.9 & 13.9 \\
\hline$>1$ to 2 & 1037 & 20.0 & 0.5 & 13.7 & 13.7 \\
\hline$>2$ & 252 & 18.7 & 0.6 & 13.6 & 13.6 \\
\hline \multicolumn{6}{|l|}{ BMI-for-age Z-score ${ }^{\ddagger}$} \\
\hline$<-2$ & 345 & 20.2 & 2.2 & 13.9 & 0.6 \\
\hline-2 to $<-1$ & 1723 & 19.2 & 0.6 & 14.0 & 0.2 \\
\hline-1 to 1 & 13004 & 19.3 & 0.2 & 13.9 & 0.2 \\
\hline$>1$ to 2 & 3507 & 19.7 & 0.3 & 13.8 & 0.2 \\
\hline$>2$ & 1177 & 19.8 & 0.5 & 13.7 & 0.3 \\
\hline \multicolumn{6}{|l|}{ Education of head } \\
\hline$<5$ (primary or less) & 8674 & 18.5 & 0.2 & 13.7 & 0.2 \\
\hline 5 to $<11$ & 10630 & 19.6 & 0.4 & 13.9 & 0.2 \\
\hline 11 to $<16$ & 9969 & 19.7 & 0.3 & 13.9 & 0.2 \\
\hline$\geq 16$ (university) & 1661 & 20.3 & 0.6 & 13.7 & 0.2 \\
\hline \multicolumn{6}{|l|}{ Wealth index, quintiles ${ }^{\S}$} \\
\hline Q1 & 15631 & 17.6 & 0.3 & 13.7 & 0.5 \\
\hline Q2 & 7497 & 18.9 & 0.3 & 13.9 & 0.1 \\
\hline Q3 & 5162 & 20.3 & 0.3 & 14.0 & 0.1 \\
\hline Q4 & 2845 & 22.9 & 0.7 & 13.7 & 0.2 \\
\hline \multicolumn{6}{|l|}{ Food insecurity in the home } \\
\hline No & 10664 & 19.6 & 0.4 & 14.0 & 0.3 \\
\hline Mild & 11115 & 19.5 & 0.2 & 13.7 & 0.2 \\
\hline Moderate & 5595 & 18.9 & 0.3 & 13.7 & 0.2 \\
\hline Severe & 3750 & 18.8 & 0.4 & 14.0 & 0.3 \\
\hline \multicolumn{6}{|l|}{ Urbanicity } \\
\hline Big cities $\|$ & 4454 & 20.4 & 0.7 & 14.6 & 0.5 \\
\hline Population from 100001 to 1000000 & 7411 & 19.5 & 0.3 & 13.8 & 0.1 \\
\hline Population from 0 to 100000 & 11502 & 19.4 & 0.3 & 13.4 & 0.1 \\
\hline Disperse population & 7768 & 17.7 & 0.3 & 13.3 & 0.2 \\
\hline \multicolumn{6}{|l|}{ Country region } \\
\hline Central & 7334 & 18.0 & 0.4 & 14.3 & 0.6 \\
\hline Atlantic (north) & 5889 & 18.3 & 0.3 & 12.9 & 0.2 \\
\hline Oriental & 5530 & 20.2 & 0.3 & 13.8 & 0.1 \\
\hline Pacific (west) & 4137 & 18.5 & 0.4 & 14.2 & 0.2 \\
\hline Bogotá & 2163 & 21.9 & 1.7 & 14.4 & 0.2 \\
\hline Amazonia-Orinoquia & 6082 & 20.2 & 0.5 & 13.0 & 0.1 \\
\hline
\end{tabular}

${ }^{*}$ Based on 24 -hour recall. ${ }^{\dagger}$ Energy-adjusted by the density method. Grams/day for every $1000 \mathrm{kcal}$ consumed: $1 \mathrm{kcal} / \mathrm{d}=4.18 \mathrm{~kJ} / \mathrm{d}$. ${ }^{\ddagger}$ According to the WHO [25]. ${ }^{\S}$ The wealth index is a composite measure of a household's cumulative living standard. The wealth index is calculated using easy-to-collect data on a household's ownership of selected assets such as televisions and bicycles, materials used for housing construction, type of water supply, and sanitation facilities [21]. "Bogotá, Barranquilla, Medellín, Cali, and Bucaramanga. 
TABle 2: Differences in animal protein intake, g/d for every $1000 \mathrm{kcal}$ consumed in Colombian population (aged from 1 to 64 years, nonpregnant women) according to sociodemographic characteristics (National Survey of Nutritional Situation in Colombia (ENSIN2015)).

\begin{tabular}{|c|c|c|c|c|}
\hline Variable & Crude difference* $^{*}(95 \% \mathrm{CI})$ & $P^{\dagger}$ & Adjusted difference $^{\ddagger}$ (95\% CI) & $P^{I}$ \\
\hline Sex & & 0.008 & & 0.031 \\
\hline Males & - & & - & \\
\hline Females & $1.1(0.3,1.9)$ & & $0.8(0.1,1.4)$ & \\
\hline Age group (y) & & 0.017 & & 0.521 \\
\hline Preschool children (1-4) & $0.6(-0.3,1.5)$ & & $1.6(0.7,2.4)$ & \\
\hline Schoolchildren (5-12) & $-2.1(-3.4,-0.7)$ & & $-0.8(-1.7,0.1)$ & \\
\hline Adolescents (13-17) & $-2.5(-3.7,-1.3)$ & & $-1.9(-3.0,-0.8)$ & \\
\hline Young adults (18-26) & $-1.7(-2.8,-0.6)$ & & $-1.2(-2.2,-0.2)$ & \\
\hline Adults (27-49) & $-0.0(-1.2,1.1)$ & & $0.3(-0.8,1.3)$ & \\
\hline Older adults (50-64) & - & & - & \\
\hline Height-for-age $Z$-score ${ }^{\|}$ & & 0.882 & & 0.486 \\
\hline$<-2$ & $0.3(-0.7,1.3)$ & & $0.5(-0.4,1.4)$ & \\
\hline-2 to $<-1$ & $-0.1(-0.6,0.4)$ & & $0.1(-0.4,0.6)$ & \\
\hline-1 to 1 & - & & - & \\
\hline$>1$ to 2 & $0.7(-0.3,1.7)$ & & $0.5(-0.5,1.5)$ & \\
\hline$>2$ & $-0.6(-1.8,0.7)$ & & $-0.5(-1.6,0.6)$ & \\
\hline BMI-for-age $Z$-score ${ }^{\|}$ & & 0.594 & & 0.871 \\
\hline$<-2$ & $0.9(-3.3,5.2)$ & & $1.0(-3.0,5.0)$ & \\
\hline-2 to $<-1$ & $-0.1(-1.0,0.9)$ & & $0.2(-0.8,1.1)$ & \\
\hline-1 to 1 & - & & - & \\
\hline$>1$ to 2 & $0.4(-0.2,1.0)$ & & $0.2(-0.3,0.8)$ & \\
\hline$>2$ & $0.6(-0.4,1.5)$ & & $0.5(-0.4,1.3)$ & \\
\hline Education of head & & $<0.0001$ & & 0.113 \\
\hline$<5$ (primary or less) & $-1.1(-1.9,-0.2)$ & & $-0.5(-1.2,0.1)$ & \\
\hline 5 to $<11$ & - & & - & \\
\hline 11 to $<16$ & $0.1(-0.7,0.9)$ & & $-0.2(-1.0,0.7)$ & \\
\hline$\geq 16$ (university) & $0.7(-0.6,2.0)$ & & $0.6(-0.8,1.9)$ & \\
\hline Wealth index, quintiles & & $<0.0001$ & & $<0.0001$ \\
\hline Q1 & $-5.3(-6.8,-3.8)$ & & $-4.7(-6.0,-3.4)$ & \\
\hline Q2 & $-4.0(-5.5,-2.5)$ & & $-3.9(-5.3,-2.4)$ & \\
\hline Q3 & $-2.6(-4.2,-1.1)$ & & $-2.6(-4.1,-1.1)$ & \\
\hline Q4 & - & & - & \\
\hline Food insecurity & & 0.090 & & 0.777 \\
\hline No & - & & - & \\
\hline Mild & $-0.1(-0.9,0.7)$ & & $0.5(-0.7,0.8)$ & \\
\hline Moderate & $-0.7(-1.6,0.2)$ & & $-0.3(-1.1,0.5)$ & \\
\hline Severe & $-0.8(-1.8,0.2)$ & & $0.0(-0.8,0.9)$ & \\
\hline Urbanicity & & 0.002 & & 0.631 \\
\hline Big cities** & - & & - & \\
\hline Population from 100001 to 1000000 & $-0.9(-2.5,0.7)$ & & $-0.6(-1.4,0.3)$ & \\
\hline Population from 0 to 100000 & $-1.0(-2.6,0.6)$ & & $0.3(-0.5,1.1)$ & \\
\hline Disperse population & $-2.7(-4.3,-1.1)$ & & $0.0(-0.7,0.8)$ & \\
\hline Country region & & $<0.0001$ & & 0.002 \\
\hline Central & - & & - & \\
\hline Atlantic (north) & $0.8(-0.2,1.8)$ & & $1.2(0.4,1.9)$ & \\
\hline Oriental & $2.2(1.2,3.2)$ & & $1.6(0.9,2.3)$ & \\
\hline Pacific (west) & $0.5(-0.7,1.6)$ & & $0.5(-0.3,1.4)$ & \\
\hline Bogotá & $3.9(2.3,5.6)$ & & $2.5(1.0,4.0)$ & \\
\hline Amazonia-Orinoquia & $2.2(1.0,3.4)$ & & $2.7(1.8,3.7)$ & \\
\hline
\end{tabular}

${ }^{*}$ Based on 24-hour recall. Energy-adjusted by the density method. Grams/day for every $1000 \mathrm{kcal}$ consumed: $1 \mathrm{kcal} / \mathrm{d}=4.18 \mathrm{~kJ} / \mathrm{d}$. ${ }^{\dagger} \mathrm{Test}$ for linear trend for ordinal predictors. For sex, urbanicity, and country region, $P$ is from ANOVA. All tests incorporated the complex sampling survey design. ${ }^{*}$ From linear regression models with protein intake as continuous result and indicator variables in the table as predictors except for height-for-age and BMI-for-age. The estimates for education come from a model that excludes the wealth index and food security, which could be on the causal path. The wealth index estimates excluded food security. ${ }^{\varsigma}$ Adjusted test for linear trend or ANOVA for ordinal or categorical correlates, respectively. "According to the WHO [25]. ${ }^{\circ}$ The wealth index is a composite measure of a household's cumulative living standard. The wealth index is calculated using easy-to-collect data on a household's ownership of selected assets such as televisions and bicycles, materials used for housing construction, type of water supply, and sanitation facilities [21]. ${ }^{* *}$ Bogotá, Barranquilla, Medellín, Cali, and Bucaramanga. 
TABLE 3: Differences in vegetal (plants) protein intake, g/d for every $1000 \mathrm{kcal}$ consumed in Colombian population (aged from 1 to 64 years, nonpregnant women) according to sociodemographic characteristics (National Survey of Nutritional Situation in Colombia (ENSIN2015)).

\begin{tabular}{|c|c|c|c|c|}
\hline Variable & Crude difference* $(95 \% \mathrm{CI})$ & $P^{\dagger}$ & Adjusted difference $^{\ddagger}(95 \% \mathrm{CI})$ & $P^{I}$ \\
\hline Sex & & 0.518 & & 0.443 \\
\hline Males & - & & - & \\
\hline Females & $-0.2(-1.0,0.5)$ & & $-0.2(-0.7,0.3)$ & \\
\hline Age group (y) & & 0.621 & & 0.950 \\
\hline Preschool children (1-4) & $-1.0(-1.9,-0.1)$ & & $-1.1(-2.1,-0.1)$ & \\
\hline Schoolchildren (5-12) & $0.9(-0.4,2.3)$ & & $0.6(-0.1,1.3)$ & \\
\hline Adolescents (13-17) & $0.2(-0.3,0.7)$ & & $0.1(-0.4,0.5)$ & \\
\hline Young adults (18-26) & $-0.3(-0.7,0.2)$ & & $-0.3(-0.8,0.1)$ & \\
\hline Adults $(27-49)$ & $-0.1(-0.7,0.4)$ & & $-0.2(-0.7,0.3)$ & \\
\hline Older adults (50-64) & - & & - & \\
\hline Height-for-age $Z$-score ${ }^{\|}$ & & 0.950 & & 0.576 \\
\hline$<-2$ & $-0.1(-0.5,0.3)$ & & $-0.0(-0.4,0.3)$ & \\
\hline-2 to $<-1$ & $-0.1(-0.3,0.1)$ & & $-0.0(-0.3,0.2)$ & \\
\hline-1 to 1 & - & & - & \\
\hline$>1$ to 2 & $-0.3(-0.6,0.1)$ & & $-0.3(-0.7,0.1)$ & \\
\hline$>2$ & $-0.4(-1.0,0.3)$ & & $-0.4(-1.1,0.3)$ & \\
\hline BMI-for-age $Z$-score ${ }^{\|}$ & & 0.349 & & 0.265 \\
\hline$<-2$ & $-0.0(-1.1,1.1)$ & & $-0.1(-1.2,1.1)$ & \\
\hline-2 to $<-1$ & $0.1(-0.2,0.4)$ & & $1.1(-0.2,0.4)$ & \\
\hline-1 to 1 & - & & - & \\
\hline$>1$ to 2 & $-0.1(-0.4,0.2)$ & & $-0.1(-0.4,0.1)$ & \\
\hline$>2$ & $-0.2(-0.6,0.3)$ & & $-0.2(-0.6,0.1)$ & \\
\hline Education of head & & 0.363 & & 0.254 \\
\hline$<5$ (primary or less) & $-0.2(-0.6,0.1)$ & & $-0.0(-0.3,0.3)$ & \\
\hline 5 to $<11$ & - & & - & \\
\hline 11 to $<16$ & $0.0(-0.3,0.3)$ & & $-0.1(-0.4,0.1)$ & \\
\hline$\geq 16$ (university) & $-0.2(-0.7,0.2)$ & & $-0.3(-0.7,0.2)$ & \\
\hline Wealth index, quintiles & & 0.894 & & 0.210 \\
\hline Q1 & $0.0(-1.0,1.1)$ & & $0.9(-0.4,2.2)$ & \\
\hline Q2 & $0.2(-0.2,0.7)$ & & $0.5(0.0,1.0)$ & \\
\hline Q3 & $0.3(-0.2,0.8)$ & & $0.4(-0.1,0.9)$ & \\
\hline Q4 & - & & - & \\
\hline Food insecurity & & 0.661 & & 0.930 \\
\hline No & - & & - & \\
\hline Mild & $-0.3(-0.6,-0.0)$ & & $-0.3(-0.5,-0.0)$ & \\
\hline Moderate & $-0.3(-0.7,0.1)$ & & $-0.2(-0.6,0.1)$ & \\
\hline Severe & $0.0(-0.5,0.6)$ & & $0.1(-0.4,0.7)$ & \\
\hline Urbanicity & & 0.009 & & 0.026 \\
\hline Big cities** & - & & - & \\
\hline Population from 100001 to 1000000 & $-0.8(-1.8,0.1)$ & & $-0.9(-1.9,0.2)$ & \\
\hline Population from 0 to 100000 & $-1.3(-2.2,-0.3)$ & & $-1.5(-2.6,-0.3)$ & \\
\hline Disperse population & $-1.3(-2.3,-0.3)$ & & $-1.7(-3.3,-0.2)$ & \\
\hline Country region & & 0.740 & & 0.941 \\
\hline Central & - & & - & \\
\hline Atlantic (north) & $-1.4(-2.7,-0.1)$ & & $-1.4(-2.3,-0.5)$ & \\
\hline Oriental & $-0.6(-1.8,0.6)$ & & $-0.2(-0.7,0.4)$ & \\
\hline Pacific (west) & $-0.1(-1.4,1.1)$ & & $-0.1(-0.8,0.7)$ & \\
\hline Bogotá & $0.0(-1.2,1.3)$ & & $-0.5(-1.5,0.5)$ & \\
\hline Amazonia-Orinoquia & $-1.3(-2.6,-0.1)$ & & $-1.0(-1.6,-0.4)$ & \\
\hline
\end{tabular}

${ }^{*}$ Based on 24-hour recall. Energy-adjusted by the density method. Grams/day for every $1000 \mathrm{kcal}$ consumed: $1 \mathrm{kcal} / \mathrm{d}=4.18 \mathrm{~kJ} / \mathrm{d}$. ${ }^{\dagger} \mathrm{Test}$ for linear trend for ordinal predictors. For sex, urbanicity, and country region, $P$ is from ANOVA. All tests incorporated the complex sampling survey design. ${ }^{*}$ From linear regression models with protein intake as continuous result and indicator variables in the table as predictors except for height-for-age and BMI-for-age. The estimates for education come from a model that excludes the wealth index and food security, which could be on the causal path. The wealth index estimates excluded food security. ${ }^{\varsigma}$ Adjusted test for linear trend or ANOVA for ordinal or categorical correlates, respectively. ${ }^{~ A c c o r d i n g ~ t o ~ t h e ~ W H O ~[25] . ~}{ }^{5}$ The wealth index is a composite measure of a household's cumulative living standard. The wealth index is calculated using easy-to-collect data on a household's ownership of selected assets such as televisions and bicycles, materials used for housing construction, type of water supply, and sanitation facilities [21]. ${ }^{* * *}$ Bogotá, Barranquilla, Medellín, Cali, and Bucaramanga. 
TABLE 4: Relative contribution (\%)* of the main sources to the total animal and vegetable protein in the Colombian population (aged from 1 to 64 years) (National Survey of Nutritional Situation in Colombia (ENSIN-2015)).

$\%$

Food

All (31135) 1 to 4 y (6803) 5 to 17 y (14233) 18 to 64 y (10099) $\begin{gathered}\text { Pregnant women } \\ (1322)\end{gathered}$

\begin{tabular}{|c|c|c|c|c|c|}
\hline \multicolumn{6}{|l|}{ Animal } \\
\hline Beef & 17.8 & 12.1 & 18.6 & 19.4 & 13.4 \\
\hline Chicken meat (poultry) & 16.3 & 15.1 & 16.0 & 17.0 & 10.8 \\
\hline Eggs & 10.5 & 13.0 & 11.7 & 9.3 & 8.5 \\
\hline Fish and shellfish & 9.1 & 8.3 & 9.1 & 9.5 & 11.5 \\
\hline Whole milk & 7.1 & 15.8 & 7.7 & 5.3 & 5.6 \\
\hline Cheese & 5.5 & 4.9 & 6.5 & 5.4 & 4.9 \\
\hline Pork meat & 5.2 & 2.8 & 5.1 & 6.4 & 4.3 \\
\hline Organ meats and other cuts of beef, pork (viscera) & 4.5 & 4.0 & 4.6 & 4.9 & 7.4 \\
\hline Noncanned processed meats & 4.1 & 3.5 & 5.1 & 3.8 & 6.3 \\
\hline Cereals $^{\dagger}$ & 3.4 & 2.4 & 2.8 & 3.9 & 6.0 \\
\hline Bread, arepa, pasta $^{\dagger}$ & 3.3 & 2.2 & 3.0 & 3.7 & 4.5 \\
\hline Potatoes $^{\dagger}$ & 1.4 & 1.5 & 0.8 & 1.7 & 2.2 \\
\hline Legumes and derived products ${ }^{\dagger}$ & 1.0 & 1.3 & 1.0 & 0.9 & 2.1 \\
\hline Cereal-based preparations, $\operatorname{roots}^{\dagger}$ & 0.9 & 0.7 & 1.2 & 1.0 & 0.7 \\
\hline Banana preparations ${ }^{\dagger}$ & 0.9 & 1.4 & 0.9 & 0.9 & 1.7 \\
\hline Fermented milks & 0.8 & 2.1 & 0.9 & 0.4 & 0.8 \\
\hline \multicolumn{6}{|l|}{ Vegetal } \\
\hline Bread, arepa, pasta & 20.0 & 17.3 & 21.9 & 20.5 & 16.8 \\
\hline Cereals & 19.8 & 19.9 & 22.0 & 19.5 & 16.2 \\
\hline Legumes and derived products & 8.2 & 7.1 & 9.1 & 7.7 & 6.3 \\
\hline Potatoes & 6.7 & 8.0 & 6.5 & 6.9 & 5.2 \\
\hline Vegetable & 4.8 & 4.9 & 3.8 & 5.4 & 5.8 \\
\hline Noncanned processed meats ${ }^{\ddagger}$ & 4.8 & 4.5 & 5.8 & 4.5 & 5.4 \\
\hline Derivatives of industrialized cereals & 4.5 & 6.1 & 4.7 & 3.4 & 4.6 \\
\hline Fruit & 4.1 & 5.7 & 3.1 & 4.2 & 6.4 \\
\hline Cereal-based preparations, roots & 2.9 & 1.4 & 3.5 & 3.1 & 2.6 \\
\hline Banana preparations & 2.7 & 3.0 & 2.8 & 2.8 & 3.6 \\
\hline Home-made drinks with water and milk (coffee) ${ }^{\ddagger}$ & 1.9 & 1.1 & 1.7 & 2.4 & 1.4 \\
\hline Packaged foods (industrialized) & 1.2 & 1.1 & 1.9 & 0.6 & 0.6 \\
\hline Home-made and industrialized desserts ${ }^{\ddagger}$ & 1.2 & 1.2 & 1.3 & 0.9 & 1.5 \\
\hline Natural fruit juice & 1.1 & 0.6 & 1.1 & 1.2 & 1.1 \\
\hline Roots, tubers & 0.9 & 0.8 & 0.7 & 1.2 & 1.4 \\
\hline Supplements and add-ons & 0.5 & 0.8 & 0.3 & 0.5 & 2.1 \\
\hline
\end{tabular}

$(n) .{ }^{*}$ For animal protein: (total animal protein per item/total animal protein) $\times 100$. For vegetal protein: (total vegetable protein per item/total vegetable protein $) \times 100 .{ }^{\dagger}$ Only the animal component in the preparation. ${ }^{*}$ Only the vegetal component in the preparation.

\section{Discussion}

In the Colombian population aged from 1 to 64 years, absolute protein intake ranges from 54.5 to $71.4(\mathrm{~g} / \mathrm{d})$, and it ranges from 31.8 to $33.4 \mathrm{~g} / 1000 / \mathrm{d}$ when adjusted for energy density. No differences were found between pregnant and nonpregnant women. The relative contribution (\%) of animal protein to total protein/day is $54.6 \%$ to $62.6 \%$. The children aged from 1 to 4 years present the greatest intake per kilogram of body weight, with $4.0 \mathrm{~g} / \mathrm{kg} / \mathrm{d}$, as well as the greatest relative contribution (\%) of animal protein to total protein/day, with $62.6 \%$. For all age groups and pregnant women, the relative contribution (\%) of total protein to energy intake is $13 \%$ to $14 \%$. Protein intake was found to be positively associated with wealth level, the region, and the degree of urbanism. Animal protein intake is positively correlated with wealth level, which is higher in the country's capital, Bogotá, and in Orinoquía-Amazonía than in other regions. Vegetable protein intake is greater in the large cities than in the medium-sized cities and towns with a dispersed population. Meat, chicken, eggs, and milk make up $51.7 \%$ of the animal protein. Bread-arepa-pasta (mainly from wheat and corn), cereal (mainly rice), legumes, and potatoes make up $54.7 \%$ of the vegetable protein. These same food items make up $55 \%$ of the total protein in the diet.

In Colombia, the 2005 and ENSIN-2015 surveys [29, 30] have estimated dietary intake as well as total proteins over the past 20 years. Since the 2005 ENSIN did not estimate protein intake according to protein source, these results cannot be compared. Nevertheless, that survey reported that at least $36 \%$ of the Colombian population had a protein intake deficit associated with poverty [30]. A multicentric study performed from 2009 to 2011 with children between 1 and 17 years of age found total protein intake to be positively associated with wealth level and excessive protein intake to be associated with a body mass index $>25$ [31]. In that same 


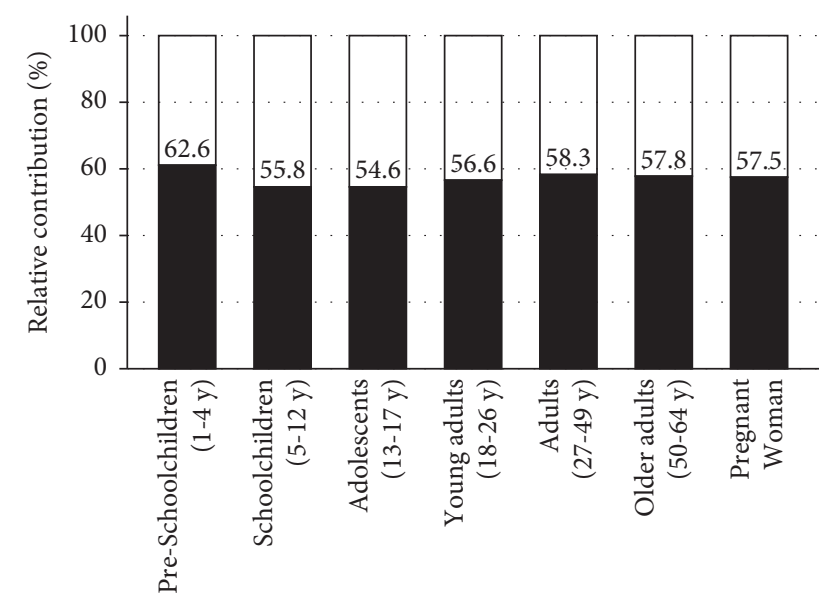

Note: Base on 24-Hour Recall Method. Intake of animal and vegetal proteins.

FIgURE 1: Relative contribution (\%) to total protein intake in the Colombian population. National Survey of Nutritional Situation in Colombia (ENSIN-2015). Animal protein (black); —vegetal protein (white) $\square$

study, the relative contribution (\%) of total protein to total energy/day was $12.0 \% \pm 0.11$ [30]. The ENSIN-2015 also reported this finding [29]. In a cohort of children in Bogotá, it was found that those in the highest quartile of adherence to the consumption of a "protein" dietary pattern had fewer behavioral problems [32].

The comparison of our findings with other national surveys is limited. In the United States, the relative contribution of animal protein to total protein is $62 \%$ for adults aged 19 years or older according to the 2007-2010 NHANES [3] and 64.6\% according to the 1999-2016 NHANES [2], compared to $58.1 \%$ in the present study for the same age group. The relative contribution of vegetable protein to total protein is $30 \%$ in the 2007-2010 NHANES [3], 35.1\% in the 1999-2016 NHANES [2], and 43\% in the present study (Table 5S). In absolute terms, women consumed less total protein than men in both the NHANES and the ENSIN-2015, but there were no significant dietary differences when adjusting by energy density and when considering intake relative to body weight. Nevertheless, the classification of the animal and vegetable sources of protein is not entirely comparable between the NHANES and the ENSIN-2015. Although absolute intake is not a good indicator, in the 2007-2010 NHANES [3], adults aged 19 years or older consumed more total protein per day on average $(82.3 \pm 0.8(\mathrm{~g} / \mathrm{d}))$ than those in the ENSIN-2015 $(67.3 \pm 1.0 \quad(\mathrm{~g} / \mathrm{d}))$. According to the French National Cross-Sectional Food Consumption Survey (INCA2; 2006-2007), [33] the average total protein intake for the adult population aged 18 years or older in France is $86.0 \mathrm{~g} / \mathrm{d} \pm 16$, relative contribution to total energy/day is $16.8 \% \pm 3.0$, animal protein intake is $60.5 \mathrm{~g} / \mathrm{d}$, and vegetable protein intake is $25.5 \mathrm{~g} / \mathrm{d}$, while the relative contribution of animal protein to total protein intake is $69.5 \% \pm 10.5$ and the relative contribution of vegetable protein is $30.5 \% \pm 10.5$.
The relative contribution of animal protein to total energy/day is $7.9 \% \pm 0.1$ in the ENSIN-2015 and $11.9 \pm 3.6$ in the 2006-2007 INCA2, [33] while vegetable protein is $5.5 \pm 0.0$ in the ENSIN-2015 and 5.7 \pm 0.1 in the 2006-2007 INCA2. According to estimates by FAOSTAT for 2014-2016, [34] total protein intake is $112 \mathrm{~g} / \mathrm{d}$ in the United States, $104 \mathrm{~g} / \mathrm{d}$ in Germany, $103 \mathrm{~g} / \mathrm{d}$ in Argentina, $100 \mathrm{~g} / \mathrm{d}$ in Canada, $97 \mathrm{~g} / \mathrm{d}$ in Egypt, $92 \mathrm{~g} / \mathrm{d}$ in Mexico, $87 \mathrm{~g} / \mathrm{d}$ in Chile, $76 \mathrm{~g} / \mathrm{d}$ in Peru, and $69 \mathrm{~g} / \mathrm{d}$ in Colombia $(4 \mathrm{~g} / \mathrm{d}$ more than in 2005). Furthermore, for those same countries and period, animal protein intake (\% of total protein) was $72 \mathrm{~g} / \mathrm{d}(64 \%)$ in the United States, $62 \mathrm{~g} / \mathrm{d}(60 \%)$ in Germany, $66 \mathrm{~g} / \mathrm{d}$ (65\%) in Argentina, $53 \mathrm{~g} / \mathrm{d}$ (53\%) in Canada, $24 \mathrm{~g} / \mathrm{d}(24 \%)$ in Egypt, $43 \mathrm{~g} / \mathrm{d}(47 \%)$ in Mexico, $28 \mathrm{~g} / \mathrm{d}$ (51\%) in Chile, $28 \mathrm{~g} / \mathrm{d}$ (36.7) in Peru, and $36 \mathrm{~g} / \mathrm{d}$ (52\%) in Colombia [34].

In the 2007-2010 NHANES, the main sources of animal protein were, in order, cheese, chicken, low-fat milk, and cured and processed meat, as well as preparations with meat and eggs, which make up an average $75.1 \%$ of the total protein. The main sources of vegetable protein are wheat bread with yeast, rolls, nuts, and seeds, as well as preparations with pasta, which contribute an average $25.3 \%$ of total protein [3]. The increase in animal protein intake in the 1999-2016 NHANES is attributable to chicken (poultry) and eggs, and the increase in vegetable protein is attributable to the consumption of whole grains, seeds, and soybean [2]. In the 2006-2007 INCA2, the main sources of animal protein are, in order, red meat, poultry and game, viscera, and processed meat, milk, and milk by-products, which make up $58.5 \%$ of total protein. The main sources of vegetable protein are cereals, which make up $19.6 \%$ of total protein [33].

Colombia is simultaneously undergoing nutrition and alimentary transition [35-38]. These results make it possible to continue to characterize the alimentary and nutritional situation of the Colombian population. According to the $\mathrm{RDA}$, protein intake is excessive, especially for children aged from 1 to 4 years, a time at which excess weight begins to be seen in Colombian children [39]. In the ENSIN-2015, excess protein intake is associated with excess kilocalorie intake and excess weight [39]. Nevertheless, in terms of the AMDR, intake is not excessive. For all age groups, the relative contribution of protein to total energy falls within a conservative range of $13 \%$ to $14 \%[5,39]$. In France, vegetable protein intake was found to be positively associated with the quality of the diet, and the quality was measured with PANDiet index [33, 40], while animal protein intake was positively or inversely associated depending on the interaction with sex and the types of foods that provided the protein source [33]. The related sociodemographic variables in the NHANES [2,3] and the 2006-2007 INCA2 [33] are similar in terms of wealth status, but the social and economic contexts are not comparable. Here it is clear that total protein intake is positively correlated with wealth level and with other indicators of social, structural, and economic development (region and degree of urbanism). Unlike the French study, the present investigation did not determine the quality of the diet, but that reflects the particularity of each country in terms of its nutritional and dietary transitions [35-38]. Therefore, it is difficult to generalize the 
conclusions or dietary interventions across countries. Although total protein and its sources can have specific effects, its consumption is directly related to other components of the diet, which is a determinant of health outcomes as well as of possible effects on the environment [4]. In Colombia, iron deficiency anemia $[29,41]$ and vitamin $B_{12}$ deficiency are public nutrition problems $[42,43]$. The former is prevalent at early ages and is inversely correlated with age, and the latter is prevalent in adults and pregnant women. Animal proteins are essential for treating these deficiencies, and, in the case of Colombia, meat, eggs, and milk are particularly important [42-44].

4.1. Scope and Limitations of the Study. The primary strength of this study is that the data were taken from a nationally representative survey that provides the best estimation available to date of dietary intake in Colombia. Estimating the amounts ( $\mathrm{g}$ ) of animal and vegetable protein in preparations that are part of the FCT is complex, but the results and the consistency with what was expected when compared to other high- and medium-income countries offer external validation of the estimation process. The findings presented herein provide key elements for adjusting and designing not only dietary policies but also public policies to control more prevalent nutritional problems and to improve health in general. The main limitation of this study is the cross-sectional design of the ENSIN-2015, due to which causal relationships cannot be determined. Another limitation is the difficulty of comparing the results with other findings that have been obtained in national surveys.

\section{Data Availability}

To access the ENSIN 2015 public database, we must register in the repository of the Ministry of Public Health, repositorio@minsalud.gov.co, and make the request through the format available at https://www.minsalud.gov.co/sites/rid/ Listas/BibliotecaDigital/RIDE/VS/ED/GCFI/forma-ensin2015.zip. The databases used to translate food consumption into proteins of animal or vegetable origin can be requested from the authors.

\section{Ethical Approval}

The study was conducted according to the guidelines laid down in the Declaration of Helsinki.

\section{Consent}

Consent for participation in the survey was obtained by the Colombian Institute of Family Welfare prior to enrolment. Ethics committee in health research of Universidad Industrial de Santander determined that analyses of these anonymized data were exempt from review.

\section{Disclosure}

The lead author affirms that this manuscript is an honest, accurate, and transparent account of the study being reported. The reporting of this work is compliant with
STROBE guidelines. The lead author affirms that no important aspects of the study have been omitted and that any discrepancies from the study as planned have been explained.

\section{Conflicts of Interest}

The authors declare that they have no conflicts of interest.

\section{Authors' Contributions}

O.H. and M.P.Z designed the research. O.H. performed the statistical analyses and had primary responsibility for the final content; O.H. and M.P.Z wrote the paper. Both authors have read and approved the final version of the manuscript.

\section{Supplementary Materials}

There are 18 tables in the supplementary file. In the first five tables $1 \mathrm{~S}$ to $5 \mathrm{~S}$, the details of the total consumption of animal and vegetable proteins are presented by sex and age groups (1-64 y, 1-4 y, 5-12 y, 13-17y, and 18-64y). The first five tables contain the following: $\mathrm{g} / \mathrm{d}$, g per $1000 \mathrm{kcal}$, the relative contribution to energy of protein consumption (\%), and the relative contribution of animal and vegetable protein consumption to total protein (\%), in addition to the protein consumption per kg of current and theoretical ideal weight. Table 6S shows the relative contribution (\%) of the main food sources to total protein in the Colombian population by age groups. Tables $7 \mathrm{~S}$ to $18 \mathrm{~S}$ present in detail the mean consumption of proteins of animal and vegetable origin for each of the categories of the covariates studied and the crude and adjusted differences in these covariates. Tables $7 \mathrm{~S}$ to $18 \mathrm{~S}$ present the information for each age group of interest $(1-4 \mathrm{y}$, 5-12 y, 13-17y, and 18-64 y). (Supplementary Materials)

\section{References}

[1] Institute of Medicine, Dietary Reference Intakes for Energy, Carbohydrate, Fiber, Fat, Fatty Acids, Cholesterol, Protein, and Amino Acids (Macronutrients), National Academies Press, Washington, DC, USA, 2005.

[2] Z. Shan, C. D. Rehm, G. Rogers et al., "Trends in dietary carbohydrate, protein, and fat intake and diet quality among US adults, 1999-2016," JAMA, vol. 322, no. 12, pp. 1178-1187, 2019.

[3] S. Pasiakos, S. Agarwal, H. Lieberman, and V. Fulgoni, "Sources and amounts of animal, dairy, and plant protein intake of US adults in 2007-2010," Nutrients, vol. 7, no. 8, pp. 7058-7069, 2015.

[4] W. Willett, J. Rockström, B. Loken et al., "Food in the anthropocene: the EAT-lancet commission on healthy diets from sustainable food systems," The Lancet, vol. 393, no. 10170, pp. 447-492, 2019.

[5] R. R. Wolfe, A. M. Cifelli, G. Kostas, and I.-Y. Kim, "Optimizing protein intake in adults: interpretation and application of the recommended dietary allowance compared with the acceptable macronutrient distribution range," Advances in Nutrition: An International Review Journal, vol. 15, no. 2, pp. 266-275, 2017.

[6] G. Wu, "Dietary protein intake and human health," Food \& Function, vol. 7, no. 3, pp. 1251-1265, 2016. 
[7] M. Song, T. T. Fung, F. B. Hu et al., "Association of animal and plant protein intake with all-cause and cause-specific mortality," JAMA Internal Medicine, vol. 176, no. 10, pp. 1453-1463, 2016.

[8] S. Naghshi, O. Sadeghi, W. C. Willett, and A. Esmaillzadeh, "Dietary intake of total, animal, and plant proteins and risk of all cause, cardiovascular, and cancer mortality: systematic review and dose-response meta-analysis of prospective cohort studies," BMJ, vol. 22, p. 370, 2020.

[9] I. Abete, D. Romaguera, A. R. Vieira, A. Lopez De Munain, and T. Norat, "Association between total, processed, red and white meat consumption and all-cause, CVD and IHD mortality: a meta-analysis of cohort studies," British Journal of Nutrition, vol. 112, no. 5, pp. 762-775, 2014.

[10] G.-C. Chen, D.-B. Lv, Z. Pang, and Q.-F. Liu, "Red and processed meat consumption and risk of stroke: a metaanalysis of prospective cohort studies," European Journal of Clinical Nutrition, vol. 67, no. 1, pp. 91-95, 2013.

[11] X. Shang, D. Scott, A. Hodge et al., "Dietary protein from different food sources, incident metabolic syndrome and changes in its components: an 11-year longitudinal study in healthy community-dwelling adults," Clinical Nutrition, vol. 36, no. 6, pp. 1540-1548, 2017.

[12] ICBF Minsalud, "Metodología ENSIN-2015," 2021, https:// www.minsalud.gov.co/sites/rid/Lists/BibliotecaDigital/RIDE/ VS/ED/GCFI/documento-metodologico-ensin-2015.pdf.

[13] A. J. Moshfegh, D. G. Rhodes, D. J. Baer et al., "The US department of agriculture automated multiple-pass method reduces bias in the collection of energy intakes," The American Journal of Clinical Nutrition, vol. 88, no. 2, pp. 324-332, 2008.

[14] C. A. Blanton, A. J. Moshfegh, D. J. Baer, and M. J. Kretsch, "The USDA automated multiple-pass method accurately estimates group total energy and nutrient intake," Journal of Nutrition, vol. 136, no. 10, pp. 2594-2599, 2006.

[15] R. Gaurth Hansen and B. W. Wyse, "Expression of nutrient allowances per 1,000 kilocalories," Journal of the American Dietetic Association, vol. 76, no. 3, pp. 223-227, 1980.

[16] J. A. Vernarelli, D. C. Mitchell, B. J. Rolls, and T. J. Hartman, "Methods for calculating dietary energy density in a nationally representative sample," Procedia Food Science, vol. 2, pp. 68-74, 2013.

[17] "AMPM-USDA automated multiple-pass method: USDA ARS,” 2020, https://www.ars.usda.gov/northeast-area/ beltsville-md-bhnrc/beltsville-human-nutrition-researchcenter/food-surveys-research-group/docs/ampm-usdaautomated-multiple-pass-method/.

[18] J. M. Conway, L. A. Ingwersen, B. T. Vinyard, and A. J. Moshfegh, "Effectiveness of the US department of agriculture 5-step multiple-pass method in assessing food intake in obese and nonobese women," The American Journal of Clinical Nutrition, vol. 77, no. 5, pp. 1171-1178, 2003.

[19] J. Lauritsen, Diet Cancer and, Society) Health Project, CDC FoodCalc, Copenhague, Denmark, 1998.

[20] FAO, Escala Latinoamericana y Caribeña de Seguridad Alimentaria (ELCSA)-Manual de uso y Aplicación, Rome, Italy, 2018.

[21] S. O. Rutstein, "The DHS wealth index: approaches for rural and urban areas," Demographic and Health Research, vol. WP60, 2008.

[22] Programa de las Naciones Unidas Para el Desarrollo (PNUD), Informe de Desarrollo Humano, PNUD, New York, NY, USA, 2013.

[23] DPN, Plan Nacional de Desarrollo, 2014-2018, DPN, Bogotá, Colombia, 2014.
[24] CDC, Measuring Children's Height and Weight Accurately at Home, CDC, Atlanta, GA, USA, 2011.

[25] WHO-World Health Organization, Patrones de Crecimiento Infantil de la OMS, World Health Organization, Geneva, Switzerland, 2011.

[26] C. L. Taylor, A. L. Carriquiry, R. L. Bailey, C. T. Sempos, and E. A. Yetley, "Appropriateness of the probability approach with a nutrient status biomarker to assess population inadequacy: a study using vitamin D," The American Journal of Clinical Nutrition, vol. 97, no. 1, pp. 72-78, 2013.

[27] StataCorp, Stata Statistical Software: Release 14, StataCorp LP, College Station, TX, USA, 2015.

[28] World Medical Association, "Declaración de helsinki de la AMM - ethical principles for human medical research," 2015, https://www.wma.net/es/policies-post/declaracion-de-helsinki-de -la-amm-principios-eticos-para-las-investigaciones-medicas-en-s eres-humanos/.

[29] "Encuesta nacional de la situación nutricional-ensin 2015," 2019, https://www.icbf.gov.co/bienestar/nutricion/encuestanacional-situacion-nutricional\#ensin3.

[30] Profamilia, Instituto Nacional de Salud, Universidad de Antioquia, OPS, and Instituto Colombiano de Bienestar Familiar, Encuesta Nacional de la Situación Nutricional de Colombia, Universidad de Antioquia, Medellín, Colombia, 2005.

[31] O. Herrán, S. DelCastillo, and G. A. Patiño, "Exceso de proteínas en la pobreza: la paradoja del exceso de peso en niños colombianos," Revista Chilena de Nutricion, vol. 44, pp. 45-56, 2017.

[32] S. L. Robinson, M. Mora-Plazas, H. Oliveros, C. Marin, B. Lozoff, and E. Villamor, "Dietary patterns in middle childhood and behavior problems in adolescence," European Journal of Clinical Nutrition, vol. 75, 2021.

[33] G. M. Camilleri, E. O. Verger, J.-F. Huneau, F. Carpentier, C. Dubuisson, and F. Mariotti, "Plant and animal protein intakes are differently associated with nutrient adequacy of the diet of French adults," Journal of Nutrition, vol. 143, no. 9, pp. 1466-1473, 2013.

[34] “FAOSTAT (2021)," 2021, http://www.fao.org/faostat/es/ \#home.

[35] N. M. Kasper, O. F. Herrán, and E. Villamor, "Obesity prevalence in Colombian adults is increasing fastest in lower socio-economic status groups and urban residents: results from two nationally representative surveys," Public Health Nutrition, vol. 17, pp. 2398-2406, 2014.

[36] O. F. Herrán, E. Villamor, and D. C. Quintero-Lesmes, "Adherence to a snacking dietary pattern is decreasing in Colombia among the youngest and the wealthiest: results of two representative national surveys," BMC Public Health, vol. 19, no. 1, p. 1702, 2019.

[37] D. C. Quintero-Lesmes and O. F. Herran, "Food changes and geography: dietary transition in Colombia," Annals of Global Health, vol. 85, no. 1, p. 28, 2019.

[38] Ó. F. Herrán, G. A. Patiño, and S. E. Del Castillo, "La transición alimentaria y el exceso de peso en adultos evaluados con base en la encuesta de la situación nutricional en Colombia," Biomedica, vol. 36, pp. 109-120, 2010.

[39] O. F. Herrán and E. M. Gamboa-Delgado, "Trends of adherence to dietary patterns in Colombian population 2010-2015," American Journal of Health Behavior, vol. 44, pp. 704-718, 2020.

[40] E. O. Verger, F. Mariotti, B. A. Holmes, D. Paineau, and J.-F. Huneau, "Evaluation of a diet quality index based on the probability of adequate nutrient intake (PANDiet) using 
national French and US dietary surveys," PLoS One, vol. 7, no. 8, Article ID e42155, 2012.

[41] R. Ramírez-Vélez, J. Correa-Bautista, J. Martínez-Torres, K. González-Ruíz, and F. Lobelo, "Ferritin levels in Colombian children: findings from the 2010 national nutrition survey (ENSIN)," International Journal of Environmental Research and Public Health, vol. 13, no. 4, p. 405, 2016.

[42] E. Villamor, M. Mora-Plazas, Y. Forero, S. Lopez-Arana, and A. Baylin, "Vitamin B-12 status is associated with socioeconomic level and adherence to an animal food dietary pattern in Colombian school children," Journal of Nutrition, vol. 138, no. 7, pp. 1391-1398, 2008.

[43] O. F. Herrán, J. B. Ward, and E. Villamor, "Vitamin B12 serostatus in Colombian children and adult women: results from a nationally representative survey," Public Health $\mathrm{Nu}$ trition, vol. 18, no. 5, pp. 836-843, 2015.

[44] O. F. Herrán, J. N. Bermúdez, and M. Del Pilar Zea, "Red meat and egg intake and serum ferritin concentrations in Colombian children: results of a population survey, ENSIN2015," Journal of nutritional science, vol. 9, pp. e12-11, 2020. 